\title{
Advisability use of Arduino controllers in automation of refrigeration devices
}

\author{
O. Pylypenko, A. Forsiuk, A. Golub, Ya. Zasiadko, V. Voznyy, R. Gryshchenko \\ National University of Food Technologies, 68 Volodymyrska str., Kyiv, 01601, Ukraine \\ e-mail: alekseypylypenko@gmail.com
}

\begin{abstract}
The advantages and disadvantages of Arduino controllers in relation to refrigeration automation systems are considered. An example of using the Arduino controller for creating an automation and monitoring system for a nonstandard laboratory refrigeration unit is presented. Arduino is a computing hardware platform for affordable design, the main components of which are the microcontroller board with input and output elements, as well as the Processing / Wiring programming environment in a programming language similar to $C, C++$. Arduino can be used to create standalone interactive objects, connect to the software that is used on your computer. The main advantage of using Arduino-based controllers is the availability of information about the microcontroller card, the specification of the elements, the software. Information is freely accessible and can be used by developers in any field. Microcontroller boards have a special structure, due to which, if necessary, it can be expanded by adding new components to the device. Thus, the presented platform allows to improve or change the operation of the automation system of the refrigeration unit, depending on the requirements of the consumer of the cold. The presented variant of automation of refrigeration systems gives an opportunity to come up with a new approach to the design of refrigeration units. During the development of the automation system, a modular algorithm for controlling and protecting the refrigeration unit was created in all its variants, the necessary peripheral equipment and signal receivers were selected. It is shown that the value ratio - functionality of these devices significantly exceeds the similar indicators of the world's leading manufacturers of refrigeration automation systems.
\end{abstract}

Key words: controller; control; refrigeration system; Arduino; automation; algorithm.

doi:

(C) The Author(s) 2019. This article is an open access publication

This work is licensed under the Creative Commons Attribution 4.0 International License (CC BY)

http://creativecommons.org/licenses/by/4.0/

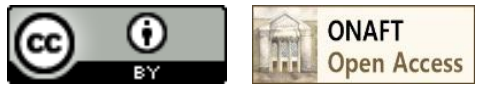

\section{Introduction}

A modern refrigeration plant is difficult to imagine without modern systems of automatic control and measurements. Along with the modern electronic automatic control systems, there are schemes developed on the basis of the relay. However, despite their significant advantage low cost, they have very significant shortcomings - low inertia and a significant error in maintaining the working parameters. Thus, the accuracy of maintaining of the evaporation and condensation pressures in the refrigeration unit equipped with the relay controls is not controlled, which leads to the increased electricity consumption in the off-design conditions. The relay control schematics, although not fully, but largely lagging behind the schematics developed on the basis of controllers. The advantage of the latter is the simplicity and ease of adjustment. The accuracy of maintaining the given technological parameters, the ability to control and regulate a large number of parameters over a wide range of refrigeration equipment are the prevailing features of the controller based systems.
There is a wide variety of controllers on the market. The simplest are parametric thermostats designed to work with one signal sensor and two or three relay outputs for controlling the cooling device and the compressor. Parametric controllers of refrigerated cabinets with two temperature sensors and three relay outputs are often used. Such devices are employed to control cooling devices, refrigeration cabinets or retail refrigeration equipment, i.e. so-called cold consumers.

The specialized parametric controllers with multiple analogue temperature or pressure inputs and a significant number of relay outputs may successfully be used for controlling compressor stations, powerful air fans of condensers, chillers and other powerful and branched equipment. Typically, parametric controllers measure air temperature, condensation pressure and boiling pressure, air cooler surface temperature. Due to the input of these parameters, controllers, in combination with peripheral executive equipment, provide a stable, reliable and energy efficient operation of the refrigeration equipment.

However, the essential disadvantage of parametric controllers is that each manufacturer of automation devices 
produces both controllers and peripherals compatible only with each other. That is, Carel controllers can only work with their electronic expansion valves, while being coupled with the Alco's equipment will work incorrectly, or they will not work at all.

Since today's main objective is maximally use the electricity in the production of artificial cold, which means it is necessary to increase the refrigeration COP, especially when running in the off-design regimes. Thus, it becomes necessary to measure a greater number of parameters than that the parametric controllers are capable of doing. Therefore, it is advisable to use powerful, freely programmable controllers with a large number of input channels for measuring various parameters, despite the fact that the cost of such controllers is higher than the that of the parametric ones.

\section{Functional capabilities of the Arduino controllers}

We propose to consider applicability of Arduino's freely programmable controllers to the creation cheap, reliable, flexible and distributed automation systems based on their capabilities. The controllers are not inferior if compared to the specialized devices of the leading manufacturers, but surpass them by some parameters.

Arduino controllers are capable of being hooked to the sensors of virtually any manufacturer. In order to maintain a correct connection, the power characteristics, the type of the primary converter and the signal coding method are to be properly taken into consideration. In the future, the signal adapts to Arduino due to the large number of specialized libraries that allow you to work with any periphery.
On top of this it should be mentioned that there is a large number of their own family diverse range of sensors, ranging from temperature transducers (digital, analogue, thermocouple, contactless thermometers), humidity (digital, analogue, resistive controllers), pressure, flow rate sensors, gas analyzers, optic and ultra sound distance measurements [1].

Various types of displays, such as monochrome LCD and color TFT, may be attached Arduino boards directly as a local display or through a separate PC [1].

Control data can be transmitted to the synchronized Smartphone or tablets with the preinstalled appropriate application. In this case the Arduino should be connected tough the Wi-Fi module to the network. Local controls include buttons, joysticks, encoders and touch pads. A smartphone can also be used for controlling and configuring the Arduino controller.

Arduino controllers can be an alternative to the standard parametric controllers (Table 1) in the event that the complex includes the following: controller (Arduino nano V3 Atmega 328P or Arduino Due R3), power supply (5V 1A), controls, display, additional relay module. All elements of the complex are installed in the common compartment [1].

As it may be seen from tabl. 1, the cost of complex based on Arduino controllers is significantly lower than the parametric analogs. Functional capabilities of the proposed complexes are not limited to pre-established algorithms for the operation of parametric devices. These and the above-mentioned advantages of the freely programmable Arduino controllers provide great opportunities for their use in refrigeration, especially in non-standard equipment.

Table 1 - Comparison of the cost of controllers $[1,3,4,5]$

\begin{tabular}{|c|c|c|c|c|c|c|}
\hline Parametric controller & $\begin{array}{c}\text { Number of } \\
\text { input / } \\
\text { output } \\
\text { channels }\end{array}$ & $\begin{array}{l}\text { Cost of the } \\
\text { parametric } \\
\text { controller, UAH }\end{array}$ & $\begin{array}{c}\text { The } \\
\text { components } \\
\text { of the } \\
\text { Arduino- } \\
\text { based } \\
\text { complex }\end{array}$ & $\begin{array}{l}\text { Number of } \\
\text { input / } \\
\text { output } \\
\text { channels }\end{array}$ & $\begin{array}{l}\text { Cost of } \\
\text { components } \\
\text { of the } \\
\text { complex, } \\
\text { UAH }\end{array}$ & $\begin{array}{l}\text { Total cost } \\
\text { of the } \\
\text { complex, } \\
\text { UAH }\end{array}$ \\
\hline Carel PJ32S0E & $1 / 1$ & 900 & $\begin{array}{l}\text { Arduino } \\
\text { Nano }\end{array}$ & \multirow{6}{*}{$\begin{array}{l}\text { Digital - } \\
14, \\
\text { Analogue - } \\
10\end{array}$} & 103 & \multirow{6}{*}{400} \\
\hline Carel PJ EZC & $\leq 3 / \leq 3$ & 1900 & $\begin{array}{c}\text { LCD } \\
\text { display }\end{array}$ & & 157 & \\
\hline Carel IRMPX & $\leq 3 / \leq 4$ & 3000 & \multirow{2}{*}{$\begin{array}{l}\text { 4-channel } \\
\text { relay } \\
\text { module }\end{array}$} & & \multirow{2}{*}{83} & \\
\hline Danfoss ERC 211 & $1 / 1$ & 1050 & & & & \\
\hline Danfoss ERC 213 & $2 / 3$ & 1200 & Encoder & & 28 & \\
\hline Danfoss EKC 202B & $3 / 3$ & 2700 & Corps & & 29 & \\
\hline OVEN UKT 38 & $8 / \leq 2$ & 3660 & $\begin{array}{l}\text { Arduino } \\
\text { Due }\end{array}$ & \multirow{6}{*}{$\begin{array}{l}\text { Digital - } \\
54, \\
\text { Analogue - } \\
16\end{array}$} & 510 & \multirow{6}{*}{807} \\
\hline OVEN TRM136 & $6 / \leq 6$ & 5130 & $\begin{array}{c}\text { LCD } \\
\text { display }\end{array}$ & & 157 & \\
\hline OVEN PLK63 & $\leq 16 / \leq 8$ & 5530 & \multirow{2}{*}{$\begin{array}{l}\text { 4-channel } \\
\text { relay } \\
\text { module }\end{array}$} & & \multirow[b]{2}{*}{83} & \\
\hline Carel pCO5 & $\leq 28 / \leq 35$ & 24700 & & & & \\
\hline Danfoss AK-PC 351 & $\leq 12 / \leq 8$ & 10200 & Encoder & & 28 & \\
\hline Danfoss AK-PC 651 & $\leq 28 / \leq 19$ & 32000 & Corps & & 34 & \\
\hline
\end{tabular}




\section{Utilization of Arduino controllers}

The system of automatic control and registration of the parameters based on the freely programmed controller Arduino Due is designed for the laboratory refrigeration unit

A one-stage laboratory unit (Figure 1) for cooling the intermediate refrigerant (propylene glycol) is equipped with a shell-tube condenser and air condenser-evaporator. The installation is designed to operate in three modes:

- liquid-liquid chiller

- "liquid-air chiller"
- "air-liquid heat pump".

In the liquid-liquid chiller mode, the refrigerant from the evaporator is compressed in the compressor, passes through the oil separator, cools down and condensed sin the flow type shell-and-tube condenser cooled by water. Then it passed through the filter-dryer, throttles down to a predetermined temperature in the expansion valve, after which the two-phase mixture completely evaporates in the shell and tube evaporator cooling the intermediate coolant. For implementation of the cycle, the electromagnetic valves 2 and 9 are open, the rest are closed. The principal lay-out of the refrigeration unit is given in Fig.1.

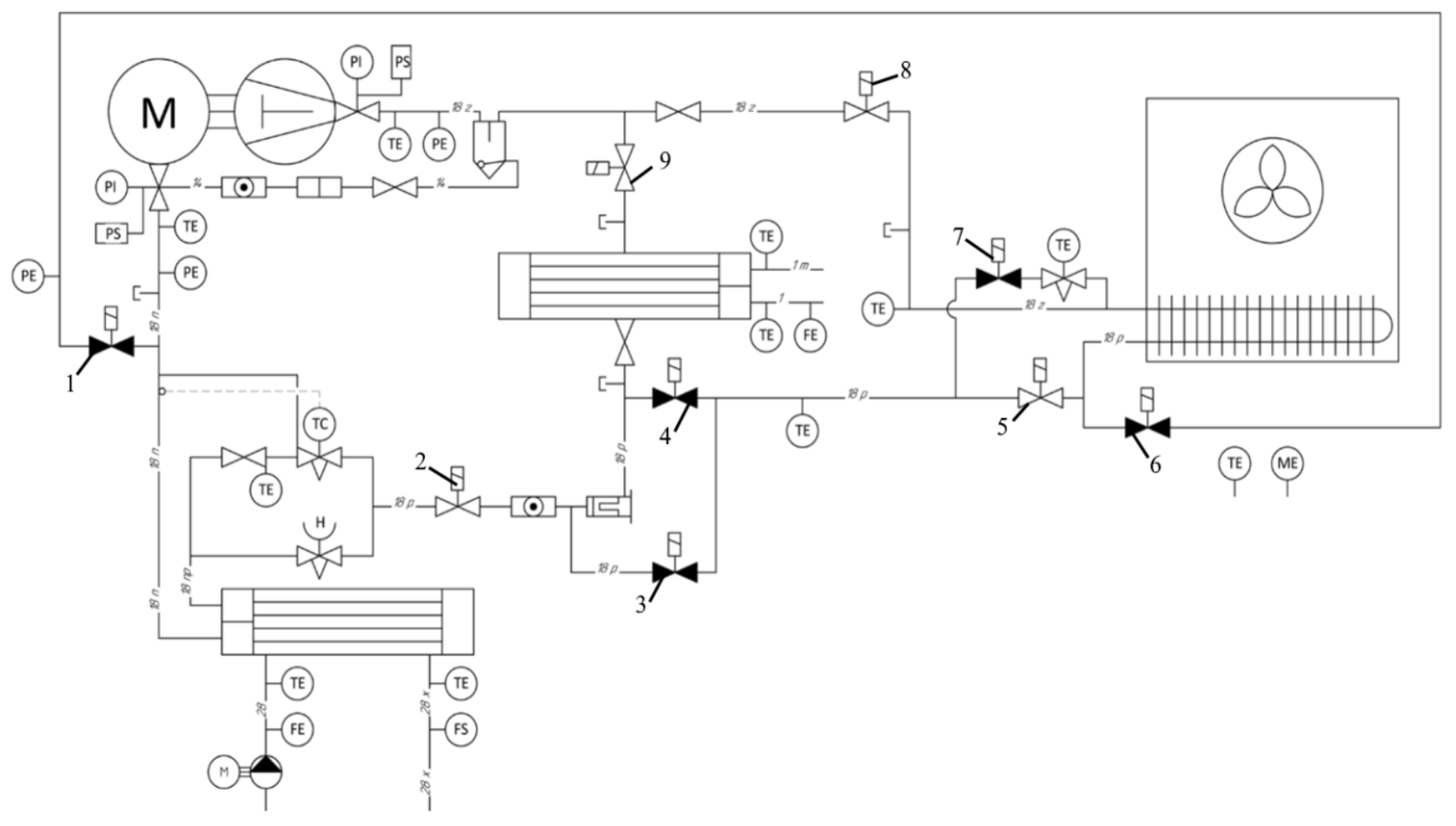

Figure 1 - The unit schematics with the positioning of sensors

Electromagnetic valves 4, 5 and 8 are open, and 1, 2, 3, 6, 7, 9 are closed.

For the "heat pump-air-liquid" mode, the solenoid valve for supplying the liquid coolant to the shell- and- tube evaporator 2 is closed, which allows it to direct coolant after the shell-tube condenser to the throttle device of the evaporator condenser. After complete evaporation of the liquid, due to heat exchange with the surrounding air, the evaporated refrigerant is sucked in by the compressor. Further movement of the refrigerant coincides with its movement when at the mode of "liquid-liquid chiller". For this mode, the electromagnetic valves $2,4,5$ and 8 are closed, and 1, 3, 6, 7, 9 are open.

Since for each mode there are identical parts of the control algorithm, the general algorithm was designed in such a way that it consisted of individual modules. Namely: the start-up module, the stop module and the protection module during operation, depending on the chosen mode of operation.

The module of the algorithm for starting the refrigerator in the "liquid-liquid chiller" mode (Figure 2) consists of the following typical modules of the unit operation algorithm:
1) Water supply to the condenser opens. The controller receives a signal from the flow relay. If the logic signal is high (relay contacts are closed) - water circulates through the condenser, if the logic signal is low (relay contacts are open) - water does not circulate.

2) The controller checks the signal from the ultrasonic level sensor. If the intermediate tank has liquid, the controller gives a high logic signal to the magnetic starter and the intermediate coolant pump starts.

3) The possibility of manual start of the pump through the start button has been foreseen.

4) If the glycol level in the tank is low, or the flow relay does not sense the movement of water in the condenser the controller signals this and will not allow the compressor to start.

5) In order to improve lubrication conditions during start-up and prevention of hydraulic shocks at this moment, which may occur due to foaming of the lubricant in the compressor crankshaft casing, the controller switches on a relay which, in turn, activates the electric heating of the compressor crankcase. The heating lasts for at least 30-40 seconds. The exact value is set when setting up the system. 
6) While the heating of the crankcase continues, the controller checks the position of the rods of all electromagnetic valves and compares them with the given, for the selected mode of operation. Under the regime under consideration, electromagnetic valves 2 and 9 are open, and $1,3,4,5,6,7,8$ are closed. Accordingly, the controller sends high logic signals on the relay that are responsible for opening the electromagnetic valves.

7) At the last step, the controller gives a high signal to the relay, which activates the magnetic starter of the compressor.

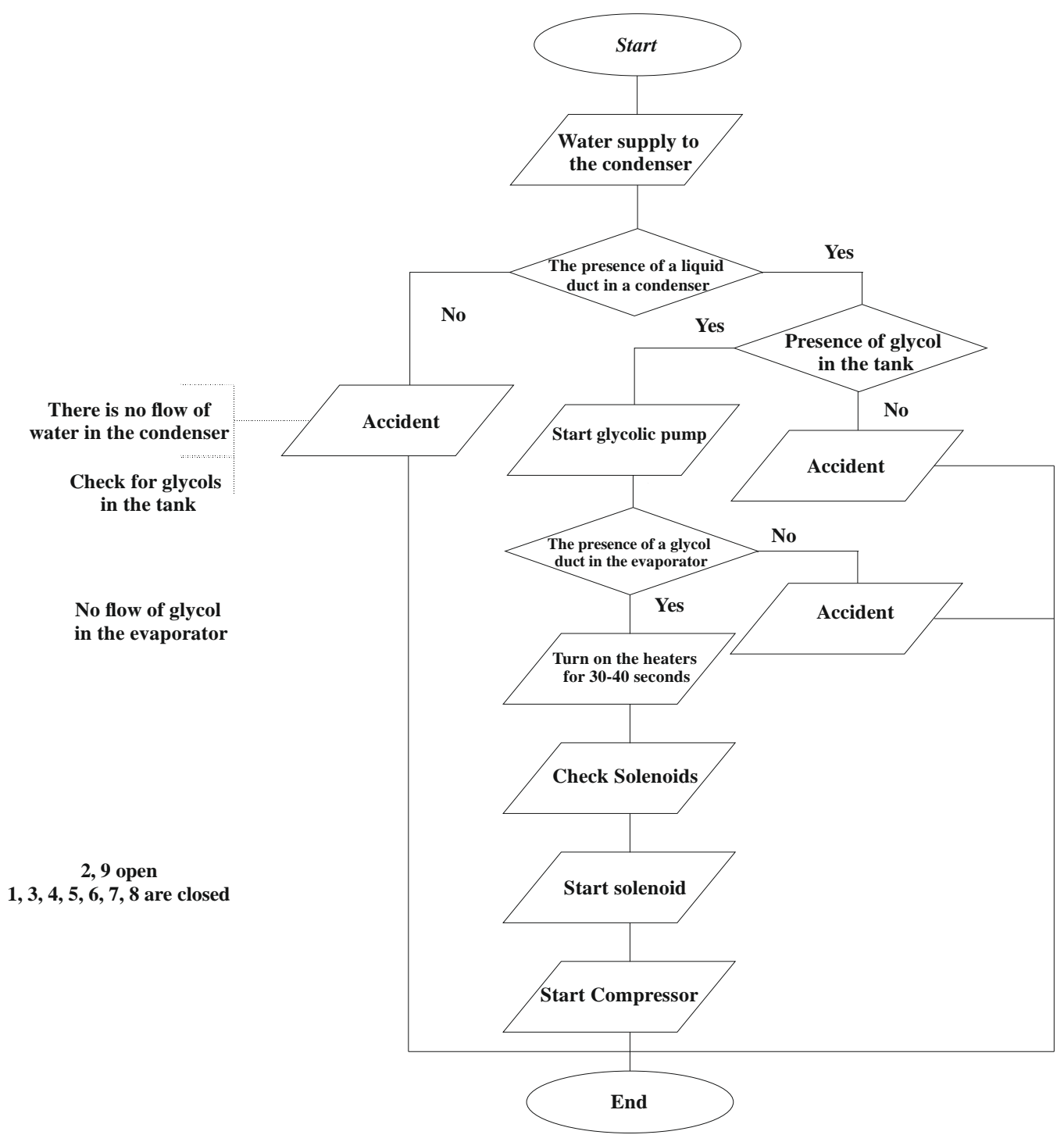

Figure 2 - Block diagram for the startup algorithm

Module of the stopping algorithm of the refrigeration unit running in the mode of "liquid-liquid chiller" is shown in (fig. 3).

For the planned stoppage, "Stop" signal from a separate button is given on the controller with the following sequence of actions:

1) The controller checks the position of the rods and closes all open electromagnetic valves except 9th (fig. 1);

2) At the same time as the valves, the controller receives a high signal from the relay controlling the intercooler pump, stopping it;

3) The installation continues to operate until the suction pressure is lowered to the lower emergency value; when it is reached, the controller is given a high signal from the relay that controls the magnetic starter of the compressor;

4) The water supply to the condenser stops.

The essence of the module of the algorithm for the protection of the refrigeration unit during operation in the "liquid-liquid chiller" mode (Figure 4) is to constantly check the parameters of work with pre-set parameters. In case of exceeding the specified parameters - the controller instantly stops the unit.

As noted in Section II, the Arduino controller can not operate the equipment without peripheral equipment and signal sensors. Therefore, the following equipment was chosen to create an automatic control system for the proposed refrigeration unit (Fig. 1) [1]: 
- digital temperature sensor Dallas DS18B20 (measuring range $-55 \ldots+125^{\circ} \mathrm{C}$, accuracy $\pm 0,5 \%$ ) - 10 units;

- digital sensor of relative humidity and temperature HTU 21 (range of temperature measurement $-40 \ldots+125^{\circ}$ $\mathrm{C}$, measurement range of relative humidity $\begin{array}{lll}0 & \ldots & 100 \% \text {, }\end{array}$ absolute temperature measurement error $\pm 0.4{ }^{\circ} \mathrm{C}$, accuracy of measurement of relative humidity $\pm 3 \%$ ) $-1 \mathrm{pc}$.;

- ultrasonic distance sensor HC - SR04 (measurement step $3 \mathrm{~mm})-1$ pc.;
- Electrow WCD - 3/4 (measuring range 1 ... $601 /$ min) -2 pcs.;

- Digital pressure gauge Emeson PT5N - 07M (measuring range $-0.8 \ldots 7$ bar, error $\pm 1 \%$ ) -2 pcs. [2];

- low pressure relay Alco Controls PS4-W1 0,3 / 1,5 (range of operation $0,3 \ldots 1,3$ bar, error $\pm 1 \% 5$ ) - $1 \mathrm{pc}$ [2].

- Dallas DS18B20 sealed temperature sensor (measuring range $-55 \ldots+125^{\circ} \mathrm{C}$, accuracy $\pm 0,5 \%$ ) -1 piece; - duct relay $3 / 4^{\prime \prime}-1$ pc.;
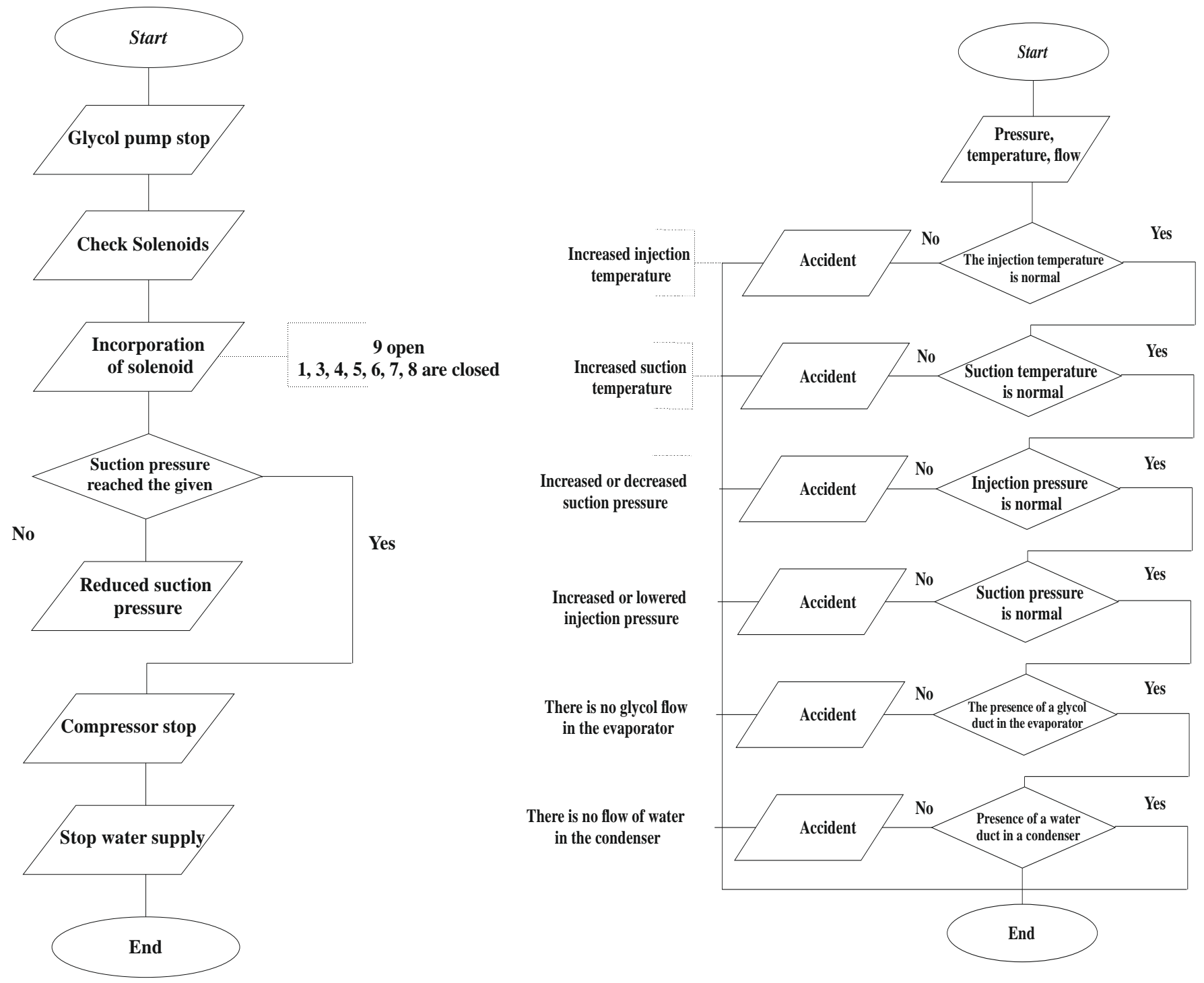

\section{Figure 3 - Block diagram for the block} algorithm

- monochrome LCD display with 20x4 extension with I2C bus -1 pc.;

- joystick for moving through the controller menu 1 pc.;

- module of the Robotdyn clock button with LED illumination -3 pcs.;

potentiometer for $200 \mathrm{k} \Omega-1 \mathrm{pc}$;

- Indicative RGB LEDs with a diameter of $5 \mathrm{~mm}-$ 6 pcs.;

- transistor module MOSFET IRF 520 - 1 pc .;
Figure 4-Block diagram for the unit's protection algorithm module during operation

- relay 8-channel module for switching voltage $250 \mathrm{~V}$ with current up to $10 \mathrm{~A}-1 \mathrm{pc}$;

- Relay 1-channel module for switching voltage $250 \mathrm{~V}$ with current up to $10 \mathrm{~A}-2$ pcs.

The total market value of the whole complex on the basis of the Arduino Due controller, excluding pressure sensors and pressure relays, amounted to about 2200 hryvnas, which corresponds to the average cost of the standard parametric controller of the refrigerating chamber. 


\section{Conclusions}

Free-programmable Arduino controllers, equipped with peripheral equipment, at cost-functionality ratio surpass modern parametric controllers of world leaders. However, for their adequate work, it is necessary to create individual algorithms for managing refrigerating systems and related software. The cost of the intellectual component of the developed program for the automation system based on Arduino will exceed the cost of components. Therefore, the use of such complexes is economically feasible only in the integrated approach to the automation of the whole refrigeration unit, either in the creation of non-standard equipment, or in the use of executive devices of different manufacturers of manufacturers.

\section{References}

1. Arduino UA. [Electronic source]. Available at: https://arduino.ua/ (Accessed: 12.12.2018)

2. INTERCOOL. [Electronic source]. Available at: http:// intercool.com.ua (Accessed :05.01.2019)

3. CAREL. [Electronic source]. Available at https://www. carel.com (Accessed: 05.01.2018)

4. Danfoss Ukraine. [Electronic source]. Available at: http://www.danfoss.ua (Accessed : 05.01.2019)

5. OVEN Oborudovanie dlia avtomatizatsii. [Electronic source]. Available at: https://owen.ua (Accessed:05.01.2019)

Received 08 January 2019

Approved 05 February 2019

Available in Internet 03 March 2019

\title{
Доцільність використання контролерів Arduino у схемах автоматизації холодильних установок
}

\author{
О. Ю. Пилипенко, А. В. Форсюк, О. В. Голуб, Я. І. Засядько, В. Ф. Возний, Р. В. Грищенко
}

Національний університет харчових технологій, вул. Володимирська, 68, м. Київ, 01601, Україна

\begin{abstract}
Розглянуто переваги та недоліки контролерів Arduіпо по відношенню до систем автоматизачії холодильних установок. Представлено приклад використання контролера Аrduіпо для створення системи автоматизаціі та моніторингу нестандартної лабораторно-дослідної холодильної установки. Агдиіпо - ие обчислювальна апаратна платформа для доступного конструювання, основними компонентами якої $\epsilon$ плата мікроконтролера з елементами «ввід» та «вивід», а також середовище програмування Processing/Wiring на мові програмування подібною до $C, C++$. Arduіпо можливо використовувати для створення автономних інтерактивних об'єктів, підключати до програмного забезпечення, яке використовується на комп'ютері. Основною перевагою у використанні контролерів на базі Arduіпо є доступність інформації про плату мікроконтролера, а саме: рисунок друкованої плати, специфікація елементів, програмне забезпечення. Інформація знаходиться у вільному доступі і може бути використана розробниками у будь-якій сфері. Плати мікроконтролера мають особливу будову, завдяки якій, при необхідності, ї̈ можливо розширювати, додаючи в пристрій нові компоненти. Таким чином представлена платформа дозволяе вдосконалювати або змінювати роботу системи автоматизації холодильної установки в залежності від вимог споживача холоду. Представлений варіант автоматизачії холодильних систем дає можливість по новому підійти до проектування холодильних установок. В ході розроблення системи автоматизації, створено модульний алгоритм керування та захисту холодильною установкою в усіх ї̈ варіантах роботи, підібрано необхідне периферійне обладнання та давачі сигналів. Показано щзо співвідношення вартість - функиіональність ичих приладів значно перевищує аналогічні показники провідних світових фірм виробників систем автоматизаціі холодильних установок.
\end{abstract}

Ключові слова: контролер; управління; холодильна система; Arduіпо; автоматизація; алгоритм.

\section{Література}

1. Arduino UA [Електронний ресурс] // Arduino UA: [сайт]. Київ, 2019. URL: https://arduino.ua/ 2. INTERCOOL [Електронний ресурс] // Intercool надежный поставщик: [сайт]. Київ, 2019. URL: http://intercool.com.ua

3.CAREL [Електронний ресурс] // CAREL INDUSTRIES
S.p.A: [сайт]. Brugine, Padova - Italy, 2019. URL: https://www.carel.com

4. Danfoss Україна [Електронний ресурс] // Danfoss Engeneering Tomorrow: [сайт]. Kyiv, 2019. URL: http://www.danfoss.ua

5. ОВЕН [Електронний ресурс] // ОВЕН оборудование для автоматизации: [сайт]. Харків, 2019. URL: https://owen.ua 